\title{
MARKET SEGMENTATION, CUSTOMERS, AND VALUE PROPOSITIONS ANALYSIS FOR POLYMER CLAY ART BUSINESS START-UP
}

\author{
Desman Hidayat ${ }^{1}$; Apriani Kurnia Suci ${ }^{2}$ Gita Khadijatu Saliha ${ }^{3}$ \\ 1,2,3 Binus Entrepreneurship Center, Bina Nusantara University, \\ Jln. K.H. Syahdan No 9, Jakarta Barat, DKI Jakarta, 11480, Indonesia \\ 1'desman_hidayat@yahoo.com; ${ }^{2}$ apriani_k_s@yahoo.com; ${ }^{3}$ gita_ks@yahoo.com
}

Received: 27 $7^{\text {th }}$ February 2016/ Revised: $22^{\text {nd }}$ April 2016/ Accepted: $2^{\text {nd }}$ May 2016
How to Cite: Hidayat, D., Suci, A. K., \& Saliha, G. K. (2016). Market Segmentation, Customers, and Value Propositions Analysis for Polymer Clay Art Business Start-Up. Binus Business Review, 7(1), 89-93.
http://dx.doi.org/10.21512/bbr.v7i1.1488

\begin{abstract}
Polymer clay art is one of the creative businesses that are recently starting to get a lot of attentions. To prepare a startup business in this field, analysis from a lot of aspects is needed. The purpose of this article was to explain the approach of the polymer clay art business startup from the market segmentation, customer, and value proposition side of the business. The method was applied by analyzing those steps in details. The analysis started from brainstorming to choose the market matching to business, the customer side, value proposition, and between both aspects. The result of the analysis shows the business focus of the polymer clay art business, where the value propositions are focusing on unique decorations, and several types of customer segments.
\end{abstract}

Keywords: polymer clay art, market segmentation, customer, value proposition, business start-up

\section{INTRODUCTION}

Unemployment is quite a big problem in Indonesia. One of the things that caused unemployment is because of the Indonesian mindset that prefers to work as an employee in a company or work with other people, while with the huge numbers of people in Indonesia, the competition with other people who are also trying to find a job will be intense.

One of the solutions for the unemployment problem is to become an entrepreneur. The ideal condition for a country to develop is when there are at least $2 \%$ of entrepreneur numbers from the total population. According to the data from Indonesian State Ministry of Cooperatives \& SMEs in 2013, currently, there are only $1,7 \%$ of entrepreneurs from the total population in Indonesia. The numbers of small and medium enterprise in Indonesia are 57,7 million, and the numbers of cooperatives are 206,750 units. (Fitriani, 2014). The government has allocated 60 billion Rupiahs funding from the 2014's Indonesian State Budget (APBN) to help entrepreneurs getting their capital investment. (Munthe, 2014).
Creative business is a business that lately has developed a lot, starting from games, art \& crafts, clothing, statues, etc. Polymer clay art is a form of creative business that will be discussed in this article. There are a lot of things to be thought about when someone decides to become an entrepreneur, from the product that he offers, customer segment, marketing, operational, finance, etc. The purpose of this article is to explain the approach of the polymer clay art business startup from the market segmentation, customer, and value proposition side of the business.

Market segmentation is very important to the business, especially for effective marketing planning. (McDonald \& Dunbar, 2013). They also summarize the advantages of segmentation as follows: (1) It is really important to recognize customers' differences because it can match what customers needs and also what the company offers. (2) Segmentation can lead to niche marketing, which can make the company do segment domination, which is hard to do if the company targets total market. (3) Focusing on a specific market can give the company great competitive advantages. (4) Segmentation also enables the company to consider 
the market in different ways from the competitors. (5) The company can become a specialist in the chosen segment, and since the company will understand more about what the customers need, then the products and services will get more advantages than our competitors'.

Furthermore, Weinstein (2004) said that to be able to compete successfully; companies should use segmentation techniques and strategies to find their competitive advantage. A value proposition should be done in the early step of the project so that it can be implemented in the company to maximize shortterm and long-term organizational performance. (Harrington \& Trusko, 2014). O’Dell and Grayson (1999) in their article defined four phase process in knowledge management and transfer, those are Phase 1: Plan, Assess, and Prepare. Phase 2: Designing the Transfer Project. Phase 3: Implementation. Phase 4: Transition and Scale-Up.

Part of the Phase 1 that should be done in the early part is to discover the value proposition. It shows that the value proposition is really important to be planned and implemented, whether it is in the relationship with the customers or within the company itself.

In the strategy map that they made, Kaplan and Norton (2014) wrote down that there are several types of customer value proposition: (1) Product/service attributes: price, quality, availability, selection, and functionality. (2) Relationship: service, partnership. (3) Image: brand. These attributes are used to explained customer perspective from the company.

\section{METHODS}

Before starting a business, there are two things that have to be done, business plan and business model canvas. A business model describes the rationale of how an organization creates, delivers, and captures value (Osterwalder \& Pigneur, 2010) .

There are nine building blocks as parts of business model canvas: (1) Customer segments; an organization serves one of several customer segments. (2) Value propositions; value propositions are the value that we create to solve customer problems and also satisfy customer needs. (3) Channels; how we deliver value propositions to the customers. (4) Customer relationships; customer relationships are established and maintained with each customer segments. (5) Revenue streams; revenue streams results value propositions successfully offered to customers. (6) Key resources; key resources are the assets required to offer and deliver the value propositions and other elements mentioned above. (7) Key activities; key activities are the activities required to deliver the value propositions. (8) Key partnership; key partnership is our partners and all of the third parties cooperating with our business. (9) Cost structure; all of the cost related to our business .

From the nine building blocks, the approach that commonly used is the approach from the customer segments, where a business need to know in details about the customer segments and also the value propositions that can be used to solve customers' problems.

Aulet (2013) explained that there are three ways for someone to start a new venture. First, having an idea that can change the world, or some part of it, in a positive way, or something that can improve the existing process, and implement it. Second, having a technological breakthrough, or already learned it and see the potential for a business. Third, having a passion, means having confidence and comfortable enough to increase your skills in the most comprehensive way.

After having one of these three ways as your background to start a new venture, then the next step that you need to do is having the market segmentation. According to Grover \& Srinivasan (1987), market segment is a group of people who has the similar thoughts in deciding the brand in a type of product.

The things that can be done to segment the market can be started by deciding which type of industries we want to enter, what is the market that we intended to sell our products, the market segment, and who will be the end user. We also need to think about how the end user will use our product or services.

At the start, we need to brainstorm to get a list of market segmentation, and then we need to focus only on several market segments since our business will not do well when it is not focused. Aulet (2013) said that there are seven questions that we can use as a benchmark to analyze and choose market opportunities: (1) Is the target customer well-funded? (2) Is the target customer readily accessible to your sales force? (3) Does the target customer have a compelling reason to buy? (4) Can you today, with the help of partners, deliver a whole product? (5) Is there entrenched competition that could block you? (6) If you win this segment, can you leverage it to enter additional segments? (7) Is the market consistent with the values, passions, and goals of the founding team?

After deciding the market segments, then we need to do the primary market research to know if the market is good enough with what the business desire. To understand more about value propositions, Osterwalder et al., (2014) used value proposition canvas that is consists of the analysis of three aspects.

First, customer profile that consists of (1) customer jobs: what your customers try to get done in their work or in their life, (2) customer pains: anything that annoys your customers before, during, and after trying to get a job done or simply prevents them from getting a job done, and (3) customer gains: the outcomes and benefits your customers want. The second aspect is value map which consists of (1) product and services: a list of what you offer, (2) pain relievers: how your products and services alleviate specific customer pains, and (3) gain creators: how your products and services create customer gains. Next, the final aspect is fit that consists of (1) on paper: problem-solution fit: do the customers really care about jobs, pains, and gains? At this stage, we 
design value propositions to do that thing, (2) in the market: product-market fit. Do the products and services, pain relievers, and gain creators really give values for the customers and interesting enough to be marketable? (3) In the bank: business model fit. Can the value propositions delivered in a business model that is profitable and can be measured?

From the mentioned theories, customer and value propositions approaches will be used for polymer clay art business. The basic idea of polymer clay art is how someone can use creativity to serve things that can give extra value, especially from the visual side.

\section{RESULTS AND DISCUSSIONS}

The first analysis will be done by deciding whether the business is good enough to be started. From the three ways to start a venture, the ability to create art from the polymer clay is a part of having the idea, and the effort and willingness to go into this business can be part of having the passion. To prepare this business, there is also a team that already has the skill in polymer clay art creative design. The next part is to do the analysis based on market segmentation:

Table 1 Industry Brainstorm Result for Market Segmentation

\begin{tabular}{|c|c|c|c|c|}
\hline Industry & Market & $\begin{array}{c}\text { Market } \\
\text { Segment }\end{array}$ & $\begin{array}{l}\text { End } \\
\text { User }\end{array}$ & Function \\
\hline \multicolumn{5}{|l|}{ Creative } \\
\hline \multicolumn{5}{|l|}{ Culinary } \\
\hline \multicolumn{5}{|l|}{ Education } \\
\hline Electronic & & & & \\
\hline
\end{tabular}

From the result of brainstorming, there are findings that a lot of kinds of industries are able to use the product that will be produced, such as creative industry, culinary, education, and also electronic, as seen in Table 1. There are a lot of markets from the creative industry, such as toys, accessories, etc. In the culinary industry, the products can be used for food display at the restaurant. It will help the customers to see the visual of the food that the restaurant served. In the education sector, polymer clay art can be used for simulation or visualization of the subject. For example, we can use it to visualize human's internal organ, so that it will be easier to study about that subject. In the electronic industry, we can use it as a design for the mobile phone case. The next thing that we need to do is to choose which industry we want to develop the products. For this case, we choose creative industry because there will be more areas to explore with the products will be sold.

Creative industry can be divided into several markets which have different targets. On Table 2, there are several markets that can be penetrated in the creative industry. The first market is the toys market, where the products of polymer clay art can be used to make toys. These toys are the toys for children or action figures. To make children's toys, is considered a way to make these toys durable, since they will be played very often. The other market that can be entered by this business is the accessories market. Accessories here include keychain, phone accessories, bracelet, hair band, display, magnet, wedding souvenir, etc. Functional market is a market where the products can be used for useful thing instead of only for accessories, such as for the office needs. Polymer clay art can be used for making timetables or paperclips to be more unique.

Table 2 Market Brainstorm Result for Market Segmentation

\begin{tabular}{lllll}
\hline \multicolumn{1}{c}{ Industry } & Market & $\begin{array}{c}\text { Market } \\
\text { Segment }\end{array}$ & $\begin{array}{c}\text { End } \\
\text { User }\end{array}$ & Function \\
\hline Creative & Toys & & \\
Culinary & Accessories & & \\
Education & Functional & & \\
Electronic & & & \\
\hline
\end{tabular}

The problem when entering the toys' market is that it will be hard to create a polymer clay art that is easy to be played with but also durable since it will be used very often. To enter the action figure market, then the quality will be the main value of our products. Also, the copyright will be a problem when the business runs well. The accessories market, shows that there are already so many competitors in this market, and if we want to enter the functional market, then the market will be very niche and specific. Thus, it need to learn more about them. Both markets are easier to enter, but in this brainstorm, it will choose the accessories market. It is better for us to focus only on one market at the beginning so that the business will be easier to develop.

Table 3 Market Segment Brainstorm Result for Market Segmentation

\begin{tabular}{|c|c|c|c|c|}
\hline Industry & Market & $\begin{array}{c}\text { Market } \\
\text { Segment }\end{array}$ & $\begin{array}{l}\text { End } \\
\text { User }\end{array}$ & Function \\
\hline Creative & Toys & $\begin{array}{l}\text { Women's } \\
\text { accessories }\end{array}$ & & \\
\hline Culinary & Accessories & $\begin{array}{l}\text { Keychain and } \\
\text { other ornaments }\end{array}$ & & \\
\hline Education & Functional & & & \\
\hline Electronic & & & & \\
\hline
\end{tabular}

There are a lot of parts in the accessories market that can be entered by this business. One of the markets is women's accessories. Women's accessories can be the accessories for the hair ties, hair bands, accessories for bracelet, etc. See Table 3 the other market segment that can be entered by this business is the ornaments segment, such as keychain, mobile phone accessories, magnet, or other unique ornaments for decoration.

Women's accessories are a big market, but it is still not common for women to use this kind of accessories. Meanwhile, on the ornaments, we also 
have a big market, but there are a lot of competitors as well, so we need to think about the innovation to have the competitive advantages. In this case, the team will choose the ornaments market because the team has more knowledge about it than women's accessories, as seen in Table 4.

Table 4 End User Brainstorm Result for Market Segmentation

\begin{tabular}{|c|c|c|c|c|}
\hline Industry & Market & $\begin{array}{c}\text { Market } \\
\text { Segment }\end{array}$ & End User & Function \\
\hline Creative & Toys & $\begin{array}{l}\text { Women's } \\
\text { accessories }\end{array}$ & $\begin{array}{l}\text { Woman, } \\
\text { children, and } \\
\text { productive age }\end{array}$ & \\
\hline Culinary & Accessories & $\begin{array}{l}\text { Keychain } \\
\text { and other } \\
\text { ornaments }\end{array}$ & $\begin{array}{l}\text { Events' } \\
\text { participants }\end{array}$ & \\
\hline Education & Functional & & & \\
\hline Electronic & & & & \\
\hline
\end{tabular}

After deciding the market segment, then we need to know who will be the end user of these products. The end user is different than the customer, in a way that the end user is people who will use the product, not buying the product. Polymer clay art can be sold in public for everyone, or can be sold for certain events. The example of events that can use this product is wedding events, where polymer clay art can be used as the wedding souvenir. The end user of this term is the participants of the event themselves. Other events that can use this product as souvenir are office event, birthday event, graduation, or other events. This souvenir will be designed as requested by the organizers of each event. To sell publicly without event, polymer clay art can be made in amusing or cute shape and nice colors so that children and women, especially in productive age, will like it.

Table 5 Function Brainstorm Result for Market Segmentation

\begin{tabular}{lllll}
\hline Industry & Market & $\begin{array}{c}\text { Market } \\
\text { Segment }\end{array}$ & $\begin{array}{c}\text { End } \\
\text { User }\end{array}$ & Function \\
\hline Creative & Toys & $\begin{array}{c}\text { Women's } \\
\text { accessories } \\
\text { Keychain } \\
\text { and other } \\
\text { ornaments }\end{array}$ & Ornaments \\
Eulinary & Accessories & & \\
Electronic & Functional & & \\
\hline
\end{tabular}

Whether the products are sold for general events or for special events, the main function of the product will be as an ornament. Ornament in this term can be keychains, mobile phone accessories, magnet, or decoration. So, from the market segmentation that has been done above, it can be concluded that a polymer clay art business is made by focusing on the creative industry, accessories market, market segment for keychain and other ornaments, and with women in productive age and also children as the end user, seen in Table 5.
To understand more about the market opportunities, will be analysed seven questions: (1) Is the target customer well-funded? The price for the ornaments made from polymer clay art is not expensive, thus, women, children's parents, and also the children themselves are able to buy the products. (2) Is the target customer readily accessible to your sales force? The target customers are everywhere, so they are accessible. It can reached by face to face or through online media, such as social media and website. (3) Does the target customer have a compelling reason to buy? Target customers will be interested in buying something unique or different. Thus, they will have a compelling reason to buy this product. (4) Can you today, with the help of partners, deliver a whole product? The sold product will be able to use right after buying, depends on the function of each product. In other words, it can deliver the whole product. (5) Is there entrenched competition that could block you? There are a lot of competitors in this industry, but there is also a big market to be reached. (6) If you win this segment, can you leverage it to enter additional segments? After we win this segment, then we can leverage the business to other markets or other industries that have been analyzed in market segmentation. (7) Is the market consistent with the values, passions, and goals of the founding team? The market is suitable enough for the goals of the company. The company can also get profit in a short time.

To understand more about the customer segments and value propositions, then it will make an approach from value proposition canvas. Firstly, the customer profile consists of three factors. (1) Customer jobs: wanting to have customized souvenir for wedding or events, wanting to find gifts for friends or children, wanting to have unique decoration, looking good in front of friends, staying up to date with the newest trend. (2) Customer pains: feeling bored with the plain refrigerator or other furniture, hard to find unique souvenir. (3) Customer gains: wanting furniture to look more attractive, wanting to have special memory of some things, easy to be recognized by other people.

From the customer profile, It is made a list by sorting all the factors from the most important to the most unimportant one: (1) Customer jobs: wanting to have unique decoration, looking good in front of friends, wanting to have customized souvenir for wedding or events, wanting to find gifts for friends or children, and staying up-to-date with the newest trend. (2) Customer pains: hard to find unique souvenir, feeling bored with the plain refrigerator or other furniture. (3) Customer gains: wanting furniture to look more attractive, wanting to have special memory of some things, easy to be recognized by other people.

Secondly, value map which consists of three factors. (1) Products and services: keychain, magnet, mobile phone accessories, and decoration. (2) Pain relievers: providing unique souvenir. (3) Gain creators: unique and attractive appearance, customizable. Then, just like customer profile, we sort the value map: (1) Products and services: keychain, decoration, 
mobile phone accessories, magnet. (2) Pain relievers: providing unique souvenir. (3) Gain creators: customizable, unique and attractive appearance. After knowing about the customer profile and the value map, then it needs to match the values with the targeted customers.

From the result in Table 6, all of the problems can be solved with the value propositions that we offered, except for customer job: up to date with the newest trend, which won't be our focus. Then, the result is summarized into the value propositions and customer segments: (1) Value propositions: key chains, decorations, mobile phone accessories, and magnets that have unique and attractive appearance, can be used as a unique souvenir, and customizable. (2) Customer segments: Teenager, Children, People who want to look more attractive, Event organizer for events like office event and wedding event, and Souvenir seekers.

The result of the value proposition canvas has matched the result of market segmentation, but this is only the analysis from the company side. To make sure that the business runs well, we need to continue the analysis by doing the primary market research.

Table 6 Testing Fit Result

\begin{tabular}{llll}
\hline \multicolumn{1}{c}{ Value } & \multicolumn{1}{c}{ Solving Customer Job } & Solving Customer Pains & Solving Customer Gains \\
\hline $\begin{array}{l}\text { Providing unique souvenir } \\
\begin{array}{l}\text { Unique and attractive } \\
\text { appearance }\end{array}\end{array}$ & $\begin{array}{l}\text { Wanting to have unique decoration } \\
\text { Lustomizable }\end{array}$ & $\begin{array}{l}\text { Hard to find unique souvenir } \\
\text { Feeling bored with the plain } \\
\text { refrigerator or other furniture }\end{array}$ & $\begin{array}{l}\text { Wanting furniture to look more } \\
\text { attractive }\end{array}$ \\
Customizable & $\begin{array}{l}\text { Wanting to have customized } \\
\text { souvenir for wedding or events }\end{array}$ & $\begin{array}{l}\text { Wanting to have special } \\
\text { memory of some things }\end{array}$ & $\begin{array}{l}\text { Easy to be recognized by other } \\
\text { people }\end{array}$ \\
& $\begin{array}{l}\text { Wanting to find gifts for friends or } \\
\text { children } \\
\text { Up to date with the newest trend }\end{array}$ &
\end{tabular}

\section{CONCLUSIONS}

Based on the analysis, one of the market segmentation that matched the polymer clay art business is creative industry, accessories market, market segment for key chains and other ornaments, with the end user consists of productive age women and children. Value propositions from the business are key chains, decorations, mobile phone accessories, and magnets that have unique and attractive appearance, can be used as a unique souvenir, and customizable, while the customer segments of this business are teenager, children, people who want to look more attractive, event organizer for events like office event and wedding event, and souvenir seekers.

\section{REFERENCES}

Aulet, B. (2013). Disciplined Entrepreneurship: 24 Steps to a Successful Startup. New Jersey: John Wiley \& Sons, Inc.

Fitriani, F. F. (2014, 28 Oct.). KABINET KERJA: Menteri Koperasi \& UKM Tunggu Arahan Jokowi, Retrieved January 18th, 2015 from http://industri.bisnis.com/ $\mathrm{read} / 20141028 / 87 / 268595 /$ kabinet-kerja-menterikoperasi-ukm-tunggu-arahan-jokowi

Grover, R., \& Srinivasan, V. (1987). A Simultaneous Approach to Market Segmentation and Market Structuring. Journal of Marketing Research, 24(2),
139-153.

Harrington, H. J., \& Trusko, B. (2014). Maximizing Value Propositions to Increase Project Success Rates. Florida: CRC Press.

Kaplan, R. S., \& Norton, D. P. (Feb 2014). Measuring the Strategic Readiness of Intangible Assets. Harvard Business Review, 21-33.

McDonald, M., \& Dunbar, I. (2013). Market Segmentation: How to Do It and How to Profit from It. West Sussex: John Wiley \& Sons, Ltd.

Munthe, M. G. (2014, 17 Mar). Pemerintah Alokasi Rp60 Miliar Untuk Pengembangan Wirausaha, Retrieved January 18, 2015 from http://industri.bisnis.com/ $\mathrm{read} / 20140317 / 87 / 211488 /$ pemerintah-alokasirp60-miliar-untuk-pengembangan-wirausaha.

O’Dell, C. \& Grayson, C. J., Jr. (1999). Knowledge Transfer: Discover Your Value Proposition. Strategy \& Leadership, 27(2), 10-15.

Osterwalder, A. \& Pigneur, Y. (2010). Business Model Generation: A Handbook for Visionaries, Game Changers, and Challengers. New Jersey: John Wiley \& Sons, Inc.

Osterwalder, A., Pigneur, Y., Bernarda, G., \& Smith, A. (2014). Value proposition design: How to create products and services customers want. New Jersey: John Wiley \& Sons, Inc.

Weinstein, A. (2004). Handbook of Market Segmentation: Strategic Targeting for Business and Technology Firms (3rd ed.). New York: The Haworth Press, Inc. 